\title{
PERANCANGAN KNOWLEDGE MANAGEMENT SYSTEM MENGGUNAKAN TOOLS "BOOK REVIEW": STUDI KASUS PADA UNIVERSITAS BINA NUSANTARA
}

\author{
Karto Iskandar \\ Jurusan Teknik Informatika, School of Computer Science, BINUS University \\ Jln. K.H. Syahdan No. 9, Palmerah Jakarta Barat 11480 \\ karto_i@binus.edu
}

\begin{abstract}
The role of knowledge in developing and maintaining an organization has been strongly regarded as a very important asset. Bina Nusantara University is one of the universities that is aware of the importance of book as main knowledge media in the learning process. Reviewing books and sharing the results can be a major resource to perform maintenance on knowledge and accelerate the learning process. A problem that occurs in Bina Nusantara University is no application to do Book Reviews. There are no tools that facilitate discussion between book reviewer and book review reader. The purpose of this research is to design features of Book Review on Knowledge Management System (KMS) in Bina Nusantara University. It is expected that book review features are useful for faculty members and staffs in doing book reviews. The methodology used in this study is literature study and design a KMS application using Microsoft SharePoint 2010 technology. Conclusion of this research is the application of KMS Book Review in Bina Nusantara University can encourage book reviewers and facilitate book review readers to discuss and interact more optimally.
\end{abstract}

Keywords: Knowledge Management System, Bina Nusantara, book reviews

\begin{abstract}
ABSTRAK
Peran knowledge dalam pengembangan dan mempertahankan sebuah organisasi telah dianggap sebagai sebuah aset yang sangat penting. Universitas Bina Nusantara merupakan salah satu perguruan tinggi yang menyadari pentingnya peran buku sebagai media knowledge utama dalam proses pembelajaran. Melakukan review buku dan saling berbagi hasilnya dapat dianggap sebagai sumber daya utama dengan melakukan pemeliharaan pada knowledge dan mempercepat proses belajar. Permasalahan yang terjadi pada Universitas Bina Nusantara adalah belum adanya wadah aplikasi untuk menampung proses Review Buku; belum ada alat bantu yang memfasilitasi terjadinya diskusi antara pelaku review buku dengan pembacanya. Tujuan penelitian ini adalah untuk merancang fitur Review Buku padaKnowledge Management System (KMS) di Universitas Bina Nusantara. Diharapkan, fitur Review Buku ini dapat menjadi alat bantu dosen dan staf dalam melakukan review buku. Metodologi yang digunakan dalam penelitian ini adalah studi literatur dan perancangan aplikasi untuk KMS dengan menggunakan teknologi Microsoft SharePoint 2010. Simpulan dari penelitian ini adalah aplikasi Book Review pada KMS Universitas Bina Nusantara dapat mendorong pelaku review buku dan memfasilitasi pelaku review buku dan pembaca review untuk berdiskusi dan berinteraksi lebih optimal.
\end{abstract}

Kata kunci: Knowledge Management System, Bina Nusantara, review buku 


\section{PENDAHULUAN}

Knowledge atau pengetahuan dianggap sangat penting dalam upaya penghidupan dan pengembangan sebuah organisasi, baik bagi para ahli maupun kelompok yang terlibat di dalamnya. Namun faktanya, sebagian besar knowledge yang ada di organisasi belum dapat dikelola dengan baik. Di samping sulitnya membangun budaya, tidak adanya aplikasi pendukung menjadi kendala utama dalam membuat Knowledge Management System (KMS) yang baik. Untuk membangun KMS dalam sebuah organisasi sangat dibutuhkan dukungan management baik dalam penetapan aturan-aturan perusahaan maupun aturan dalam pengembangan aplikasi dalam KMS itu sendiri.

Bila knowledge tidak diciptakan ataupun dikembangkan, tidak ada knowledge yang terbentuk untuk dapat dimanfaatkan oleh organisasi. Knowledge yang sudah dikelola dengan baik dan mudah diakses akan sangat bermanfaat bagi organisasi untuk pengembangan organisasi menjadi lebih cepat. Knowledge harus dipelihara dengan baik, sehingga dapat diciptakan, dikembangkan, diperbarui, dan digunakan terus menerus. Dengan begitu, sebuah organisasi dapat berkembang lebih cepat dengan mengurangi adanya pengerjaan hal yang sama kembali.

Bina Nusantara (BINUS) merupakan organisasi swasta di Indonesia yang begerak di bidang pendidikan. Di BINUS terdapat beberapa institusi pendidikan, seperti universitas S1-S3, sekolah international, sampai tempat kursus yang disebut Binus Center. Sebagai institusi pendidikan, tentunya buku merupakan media knowledge utama. Buku menjadi sumber utama dalam proses pembelajaran. Proses membaca buku menjadi tugas utama bagi para tenaga pengajar atau dosen atau guru dan karyawan BINUS guna mempercepat penambangan pengetahuan dan menambah daya saing organisasi dengan kompetitornya.

Buku yang dibaca haruslah di-review dan dibagikan kepada pembaca lainnya. Kemudian diskusi terjadi terkait isi dari buku tersebut. Lalu, proses berlanjut pada penulisan buku baru. Untuk mendukung proses Review Buku tersebut sebaiknya didukung oleh sebuah sistem aplikasi yang baik. BINUS membutuhkan aplikasi yang terintegrasi dalam Knowledge Management System yang telah dimiliki saat ini.

Microsoft SharePoint 2010 merupakan teknologi berbasis Microsoft SharePoint yang dibuat oleh Microsoft Corp. sebagai software penyedia sarana bagi pengguna untuk berkolaborasi, berbagi dokumen dan mempermudah pencarian dokumen. Dengan Microsoft SharePoint 2010 ini, aplikasi review buku tersebut akan dikembangkan. Berdasarkan pengalaman dalam mengimplementasikan Microsoft SharePoint 2010 sebagai media Knowldege Management, maka masalah tersebut dapat diselesaikan dengan tools ini. Oleh karena itu, penelitian ini bermaksud untuk mengimplementasikan Microsoft SharePoint 2010.

Penelitian ini membahas tentang perancangan KMS aplikasi Review Buku yang diimplementasikan pada BINUS sebagai sebuah wadah yang terintegrasi para tenaga pengajar, dosen, guru, dan karyawan untuk saling melakukan review buku sebagai bentuk dari knowledge sharing sehingga knowledge yang ada dapat diciptakan, diidentifikasi, dikelola, dan didokumentasikan dengan baik untuk dimanfaatkan dan dikembangkan sesuai kebutuhan organisasi. Tujuan penelitian ini adalah untuk mengidentifikasi dan merancang Knowledge Management System aplikasi review buku dalam sebuah organisasi berbasis pendidikan. Membangun aplikasi Knowledge Management System berbasis MicrosoftSharePoint 2010 sebagai wadah yang dapat memfasilitasi para tenaga pengajar atau dosen atau guru dan karyawan untuk melakukan review buku. Memfasilitasi wadah penampung untuk dibaca kembali hasil review buku, menyediakan wadah untuk diskusi antara pembaca review buku dan pelaku review buku di dalam organisasi, khususnya, di Bina Nusantara. 


\section{METODE}

Penelitian menggunakan metodologi studi literatur dan perancangan aplikasi Review Buku dalam KMS. Sedangkan pengembangan aplikasi Review Buku dalam KMS menggunakan model iterasi pada masing-masing tahapan Review Buku, pembacaan ulang hasil review buku, pemberian komentar, pengiriman email kepada Reviewer, dan memfasilitasi media untuk berdiskusi.

\section{Software Development}

Incremental process model atau disebut model iterasi merupakan salah satu metode perancangan software dengan perulangan (iterasi) yang berurutan. Incremental process model pada iterasi pertama merupakan inti dari software secara keseluruhan. Untuk pengembangan lanjutan dan evaluasi sistem dilakukan pada iterasi berikutnya. Iterasi tersebut dilakukan untuk mendapatkan umpan balik dan kebutuhan yang sesuai dengan kebutuhan pengguna beserta penambahan fitur tambahan atau fungsionalitas yang dibutuhkan. Proses tersebut terus diulang hingga pada proses deployment sampai menghasilkan software yang lengkap (Pressman, 2010:41).

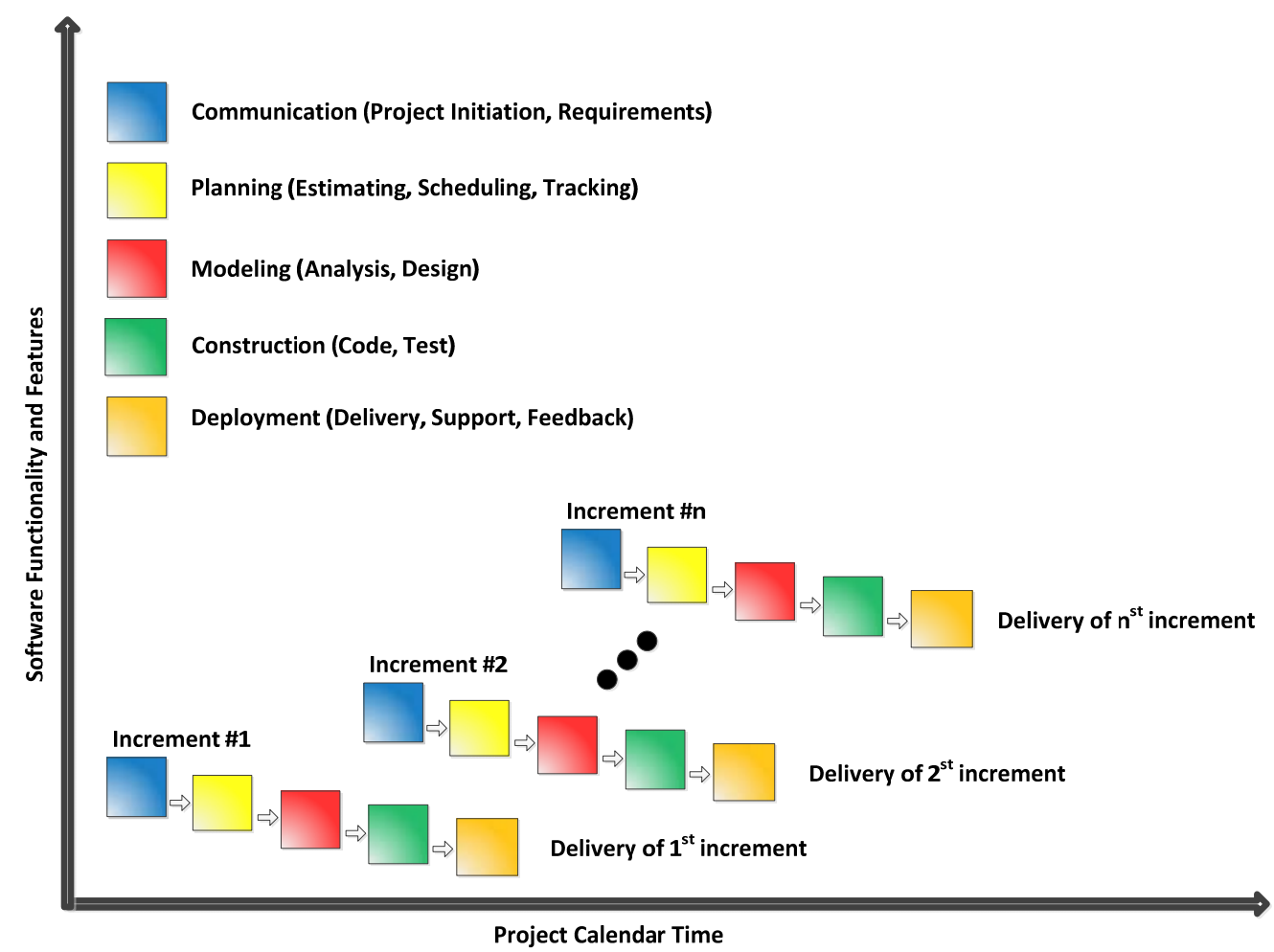

Gambar 1 Model Iterasi

Metodologi software development untuk pengembangan aplikasi Review Buku untuk KMS dengan menggunakan model iterasi dengan increment pada masing-masing tahapan review buku, yaitu: review buku, membaca hasil review buku, memberikan komentar, sistem otomatis mengirim email, dan memfasilitasi diskusi antara pembaca dan pelaku review buku. Untuk masing-masing tahapan dilakukan perulangan: Communication, Planning, Modeling, Construction, dan Deployment. Masing-masing increment menghasilkan satu kesatuan aplikasi Review Buku untuk KMS. 


\section{Knowledge Management System}

Knowledge Management System mengacu pada penggunaan teknologi informasi yang modern seperti internet, intranet, extranet, data warehouses untuk mengatur, meningkatkan, dan memperlancar intra- dan inter- knowledge management (O’Brien \& Marakas 2005). Knowledge Management System adalah cara untuk mencapai tujuan dari knowledge management yang diterapkan oleh perusahaan dan kelompok industri dengan menggunakan teknologi informasi. Knowledge Management System mencakup beberapa kondisi hard environment seperti peralatan teknologi informasi, dan serangkaian kondisi soft environment seperti sistem organisasi (Chen \& Xu, 2010).

Menurut Groff dan Jones (2003), ada dua tipe utama dari knowledge. Tipe yang pertama dan paling umum adalah tacit knowledge. Tipe yang kedua adalah explicit knowledge. Tacit knowledge mengacu pada knowledge pribadi yang melekat dalam pengalaman individu dan melibatkan faktorfaktor seperti keyakinan, perspektif, dan nilai-nilai pribadi. Tacit knowledge sulit untuk dipindahkan. Explicit knowledge mengacu pada tacit knowledge yang sudah didokumentasikan. Explicit knowledge biasanya dalam bentuk bahasa formal dan lebih mudah dipindahkan antara individu-individu.

Menurut Evers, Gerke, dan Menkhoff (2010), tacit knowledge pada dasarnya adalah pengalaman yang diperoleh melalui tindakan, sedangkan explicit knowledge mengacu pada pengetahuan yang disimpan dan dibuat dalam buku, bank data, atau jenis media lainnya. Memelihara kompetensi dalam sebuah organisasi, meskipun turnover karyawan tinggi baik melalui pensiun atau pengurangan biaya atau tidak perpanjang kontrak atau pindah ke organisasi lain, menimbulkan tantangan manajemen karena tacit knowledge hilang.

Menurut Tobing (2007), komponen utama dari knowledge management adalah people, process, dan technology. Masing-masing dari komponen ini akan saling terkait satu sama lain serta saling terintegrasi membentuk suatu landasan yang kuat untuk knowledge management. Lebih lanjut, menurut Tobing (2007), untuk mengatur dan mengelola knowledge yang terdapat pada organisasi dapat dimulai dengan mengelompokkan dan mengategorikan masalah yang ditemui di dalam organisasi. Hal ini dilakukan untuk mengidentifikasi kegiatan-kegiatan yang dianggap sebagai proses inti knowledge management yang terkait antara satu dengan yang lainnya.

Dari segi teknologi, menurut Evers, Gerke, dan Menkhoff (2010), teknologi informasi dalam sebuah knowledge management dapat diukur dengan mempertimbangkan dimensi konvergen dan dimensi divergen. Dimensi konvergen dinilai dari cara sebuah teknologi informasi membantu perkembangan komunikasi dan kolaborasi dalam pengembangan produk, baik di dalam maupun di luar organisasi. Sedangkan dimensi divergen dapat diukur dari seberapa besar peranan teknologi informasi memfasilitasi pengumpulan, penyimpanan, pemetaan dan format sebuah knowledge secara cepat, sehingga membantu penciptaan knowledge dalam pengembangan produk.

Menurut Chen dan Xu (2010), Knowledge Management System adalah cara untuk mencapai tujuan dari knowledge management yang diterapkan oleh perusahaan dan kelompok industri dengan menggunakan teknologi informasi. Knowledge Management System mencakup beberapa kondisi hard environment seperti peralatan teknologi informasi dan serangkaian kondisi soft environment seperti sistem organisasi.

\section{Microsoft SharePoint 2010}

Menurut Rajagukguk (2010), SharePoint didefinisikan sebagai sebuah platform perangkat lunak yang dikembangkan oleh Microsoft dengan tujuan untuk memudahkan kolaborasi di web. SharePoint digunakan untuk saling berkolaborasi dengan rekan kerja dalam membuat konten yang dinamis. 
SharePoint memiliki user experience dan pengaturan konten yang baik sehingga sangat memudahkan pengguna ketika sedang berinteraksi dengan aplikasi tersebut. SharePoint dapat diintegrasikan dengan produk Microsoft Office lainnya. Sebagai contoh, SharePoint dapat diintegrasikan dengan Office Word. Bentuk kolaborasinya adalah dokumen Word dapat disimpan dalam SharePoint dan pengguna yang berhak dapat menyunting dokumen tersebut. Ketika dokumen tersebut telah selesai disunting, dokumen tersebut dapat disimpan dalam SharePoint, semua status perubahan dokumen serta orang yang mengubahnya tercatat dalam SharePoint. Pengaturan konten di SharePoint juga didukung oleh adanya fitur versioning. Fitur versioning ini dapat melacak semua perubahan yang terjadi pada konten di dalam web SharePoint, bahkan menyimpan setiap perubahan yang dilakukan pengguna, sehingga pengguna dapat melihat dan mengembalikan versi konten sebelumnya. Menurut Pialorsi (2011:13), arsitektur SharePoint 2010 adalah sebagai berikut:

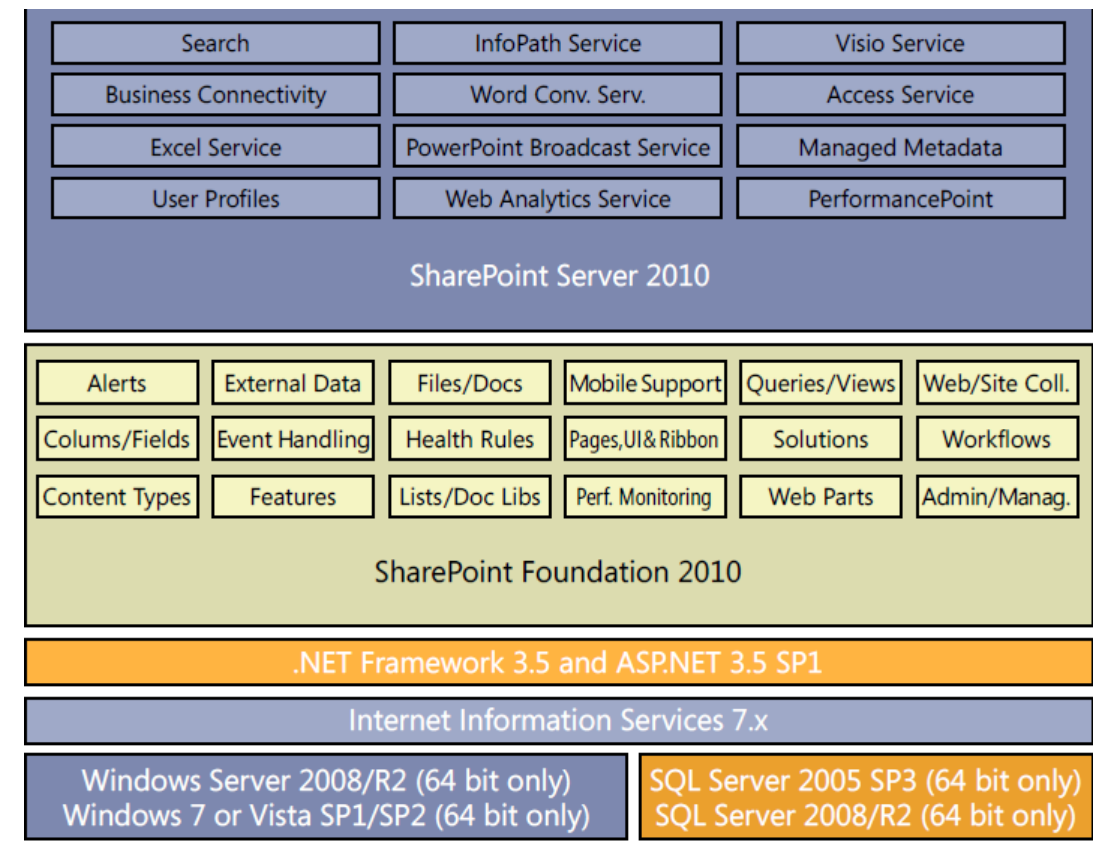

Gambar 2 Arsitektur Microsoft SharePoint 2010

Menurut Rajagukguk (2010:2-7), SharePoint memiliki enam pilar utama untuk mendukung fungsinya sebagai sebuah situs kolaborasi yang tangguh. Enam pilar tersebut adalah sebagai berikut (Gambar 3). Pertama, sites. SharePoint didukung oleh adanya ribbon yang user-friendly, ribbon tersebut terdapat pada semua produk Microsoft, dengan tampilan yang memudahkan pengguna ketika berinteraksi dengan aplikasi SharePoint. Situs SharePoint juga dapat ditampilkan pada mobile device. Office Web Application di SharePoint dapat memudahkan pengguna dalam membaca, menulis, dan mengubah konten situs langsung di browser tanpa harus menginstal Microsoft Office di komputer pengguna. SharePoint mendukung kolaborasi melalui intranet, extranet, dan internet. Tujuan utama SharePoint adalah untuk mendukung kolaborasi antarpengguna di situs. Kontainer paling luar dari SharePoint adalah server yang di dalamnya mengandung beberapa web application. Kemudian di dalam web application bisa terdapat beberapa site collection. Dalam site collection pengguna SharePoint berinteraksi.

Kedua, communities. Sebuah situs kolaborasi tentunya tidak akan berarti kalau tanpa orangorang atau komunitas yang menggunakannya dengan baik. Membagi konten ke sesama pengguna SharePoint adalah sebuah kunci penting dalam membangun sebuah komunitas. Dukungan fitur di SharePoint dapat digunakan untuk mendukung kolaborasi konten. Koneksi antara pengguna dalam 
SharePoint dapat dilakukan dengan memanfaatkan my sites. Sehingga, setiap pengguna dapat memiliki halaman situsnya sendiri dan juga dapat dilihat oleh pengguna lainnya. Kemudahan untuk berpartisipasi dalam berbagai konten adalah salah satu faktor pembangun komunitas. Pengguna dapat melakukan tagging dan rating terhadap konten pengguna lainnya.

Ketiga, content. Konten menjadi perhatian penting dalam sebuah situs karena di balik sebuah situs terdapat konten yang baik. SharePoint mendukung interaksi yang intuitif dengan Microsoft Office ketika sedang mengisi sebuah konten menjadi andalan SharePoint. Pengaturan konten yang sesuai dengan kebijakan legal dapat diatur dalam SharePoint. Kebijakan tersebut dapat diterapkan mulai dari situs sampai ke item detail yang ada di dalamnya, sesuai dengan aturan dalam organisasi terhadap pengguna tertentu. Efisiensi dalam pengaturan konten supaya terstruktur dapat dilakukan dengan dukungan metadata. Media penyimpanan berkas dengan binari yang lebih kecil terdapat dalam SharePoint.

Keempat, search. Pencarian sebuah konten menjadi salah satu tindakan yang penting dan paling sering dilakukan pengguna untuk menemukan konten yang dibutuhkan. Fitur pencarian dalam SharePoint memiliki navigasi yang mempermudah pengguna dalam melakukan pencarian konten. Pencarian dalam SharePoint mendukung pengayaan informasi dalam bentuk fonetik dan berbagai bahasa. Kemudahan dalam menemukan sebuah konten didukung dengan adanya metadata dan filtering.

Kelima, insights. Sebuah situs kolaborasi yang tangguh harus dapat menyediakan fitur yang dapat memberikan wawasan mengenai apa yang terjadi dalam organisasinya. Hal ini didukung dengan adanya excel services yang dapat digunakan sebagai sumber analisis data lengkap dengan visualisasinya. Kemudahan untuk merepresentasikan hasil analisis data didukung dengan adanya dashboard.

Keenam, composites. SharePoint mendukung sistem komposit, yang berarti bahwa konten maupun fitur dari SharePoint dapat dikembangkan dengan solusi dari pihak ketiga. Konektivitas untuk mengambil data dari sistem lain dipermudah dengan adanya Business Connectivity Services. Data dari SharePoint pun dapat digunakan oleh pihak lain dengan menggunakan Web Services atau API. Pengujian solusi atau fitur yang dibuat oleh pihak ketiga dapat dipasang tanpa menggangu situs atau services yang sedang berjalan. Hal ini didukung dengan fitur sand box, yang melalui fitur tersebut dapat diuji terlebih dahulu sebelum dipasang untuk penggunaan secara menyeluruh.

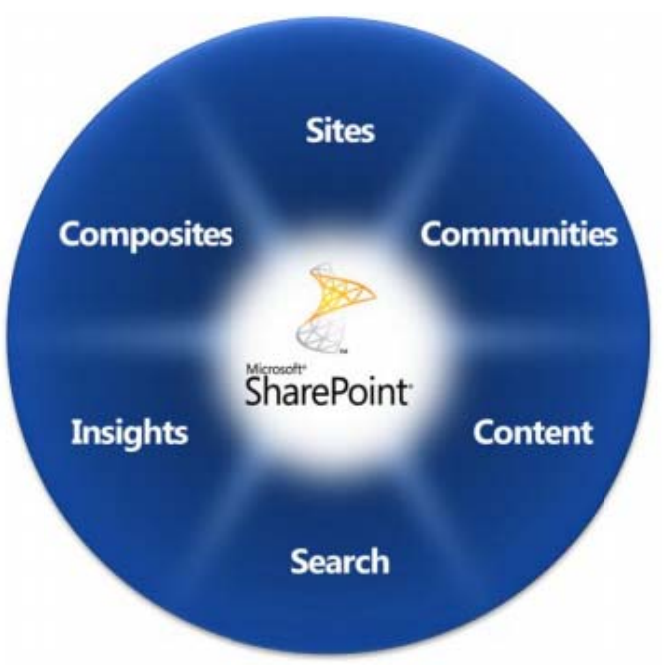

Gambar 3 SharePoint 2010 Capabilities 


\section{Book Review}

Banyak ilmuwan sukses telah menulis banyak buku. Oleh karena itu, buku yang ditulis adalah kumpulan informasi tentang ilmu yang layak untuk dibaca dan disimpulkan intisarinya (Huang \& Yang, 2008). Pengalaman merupakan guru yang berharga; dengan begitu, belajar dari pengalaman adalah hal yang penting, agar tidak kembali melakukan kesalahan yang sama. Banyak yang menemukan kegagalan demi kegagalan dalam melakukan sesuatu. Dengan tidak hanya belajar dari pengalaman sendiri, tetapi juga disarankan belajar dari pengalaman dari orang lain. Dengan aktivitas menulis atau me-review sebuah buku, maka secara tidak langsung telah belajar dari pengalaman orang lain.

Menurut Liu, Chen, dan Chiu (2013), sebuah resensi buku adalah suatu bentuk kritik sastra. Buku dianalisis berdasarkan isi, gaya, dan merit. Sebuah resensi buku dapat sepotong pendapat sumber utama, review ringkasan, atau review ilmiah. Buku dapat ditinjau untuk dicetak majalah, majalah dan koran, sebagai pekerjaan sekolah. Sebuah resensi buku yang panjang mungkin berbeda dari satu paragraf ke esai substansial. Ulasan tersebut dapat mengevaluasi buku berdasarkan selera pribadi. Reviewer dapat menggunakan kesempatan ulasan buku untuk tampilan pembelajaran atau untuk menyebarluaskan ide-ide mereka sendiri pada topik karya fiksi atau nonfiksi.

Menurut Zinkhan dan Clark (1995:108), review literatur dan review buku memainkan peran penting dalam meningkatkan pemahaman mendalam terhadap subjek yang ingin dicapai. Me-review sebuah buku dengan alasan bahwa banyak sekali buku yang dibaca, namun kemudian lupa, disebabkan karena jarang sekali pembaca buku memberikan simpulan dalam bentuk tertulis terhadap buku yang telah dibaca.

Yang penting dalam me-review buku adalah bukan menulis kembali sebuah buku, melainkan hanya meringkas pesan-pesan sebuah buku dengan seringkas mungkin dan mewakili gambaran isi dari buku itu. Dalam melakukan review buku, hal pertama yang harus dilakukan adalah membaca buku yang ingin di-review. Ini penting karena untuk mendapatkan intisarinya, perlu membaca terlebih dahulu buku tersebut. Hal ini menghindari review yang terkesan kosong dan akan tampak seperti hidup. Baru kemudian menuliskan kembali apa yang dipahami terhadap buku tersebut dengan bahasa dan kalimat sendiri. Ada banyak hal yang dapat ditulis kembali dalam review sebuah buku, bisa dari latar belakang penulis, bisa dari tren kondisi atau latar belakang kondisi penulisan buku, bisa dari kelayakan ketebalan buku, gaya bahasa buku, target pembaca buku, sampai pada harga buku. Semua hal tersebut akan menjadikan hal menarik untuk dilakukan diskusi antara pelaku review buku dengan pembaca hasil review buku.

\section{HASIL DAN PEMBAHASAN}

Penelitian ini merupakan penelitian lanjutan dari penelitian tentang perancangan Knowledge Management System (KMS) pada BINUS (Iskandar, Tony, Phankova, \& Agustino, 2013). Penelitian kali ini adalah dengan menambahkan aplikasi Review Buku pada KMS yang telah ada dengan menggunakan fitur List atau Doc Library. Fitur ini dianggap sesuai untuk kebutuhan-kebutuhan pada aplikasi Review Buku, seperti adanya informasi review buku, upload gambar untuk mengunggah cover buku, serta beberapa informasi field tambahan seperti Judul Buku, Pelaku Review, Penulis Buku, ISBN Buku, dan waktu review.

Dari hasil pengamatan, dapat ditemukan tenaga pengajar, dosen, guru, dan karyawan telah banyak melakukan baca buku namun masih jarang melakukan review buku. Buku yang dibaca haruslah di-review dan hasil review tersebut dibagikan ke pembaca lainnya yang memiliki minat yang 
sama. Kemudian, terjadi diskusi terkait isi dari buku tersebut dan setelah itu berlanjut pada proses penulisan buku baru. Proses Review Buku tersebut akan didukung oleh sebuah sistem aplikasi review buku yang terintegrasi dalam KMS yang telah dibangun sebelumnya.

\section{Perancangan Sistem yang Diusulkan}

Aplikasi Review Buku dalam KMS yang disediakan diharapkan dapat membantu dalam melakukan review buku di BINUS. Aplikasi tersebut berfungsi sebagai media sharing para tenaga pengajar, dosen, guru, dan karyawan untuk saling berbagi hasil review buku yang telah dilakukan. Selain itu, aplikasi KM tersebut dapat digunakan untuk mendokumentasikan hasil review buku yang ada sehingga dapat mengembangkan proses pembelajaran dan memudahkan dalam melakukan pencarian hasil review buku yang telah dilakukan sebelumnya.

Pada tahap modeling dalam Metodologi Iterasi, terdapat tahapan analisis dan desain. Berdasarkan hasil analisis, kemudian dilakukan perancangan. Aktor dalam aplikasi Review Buku ini ada 2, yaitu Book Reviewer dan Book Reviewer Reader. Masing-masing aktor dapat melakukan masing-masing aktivitas yang berbeda, Book Review dapat melakukan Review Buku dan berdiskusi terhadap komentar yang diberikan oleh Book Reviewer Reader. Sedangkan Book Reviewer Reader dapat melakukan membaca hasil review, memberikan komentar, dan berdiskusi dengan Book Reviewer. Hubungan aktor dengan aktor lain serta aktivitas dapat dilihat pada gambar Use case aplikasi Review Buku dapat dilihat pada Gambar 4.

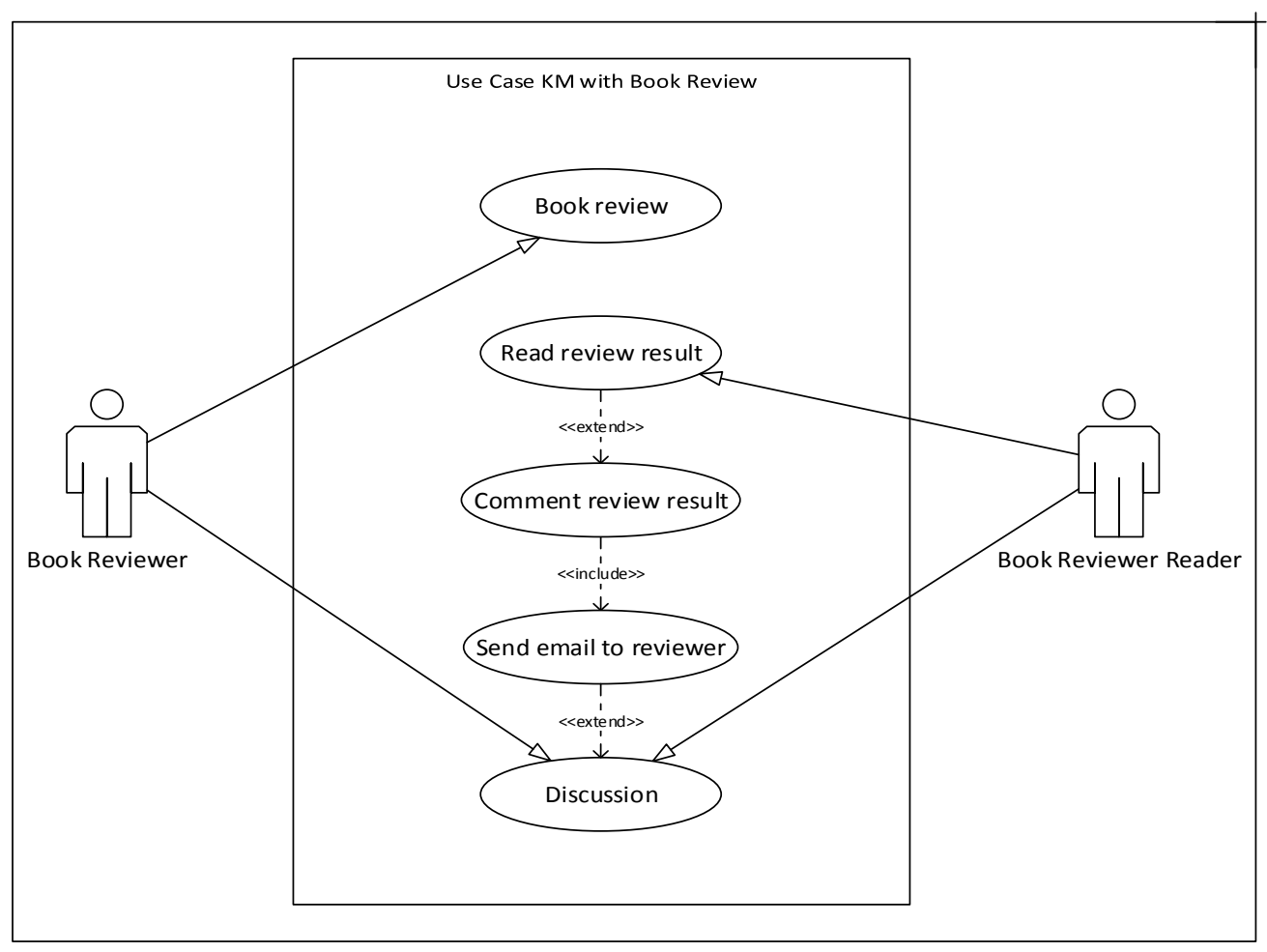

Gambar 4 Use Case Aplikasi Review Buku

Sementara itu, aplikasi Book Review merupakan bagian dari KMS yang telah ada dengan terintegrasi pada bagian Reference. Hal itu merupakan bagian dari sumber referensi yang dapat memperkaya organisasi. Perancangan aplikasi Book Review yang terintergrasi dalam system KMS yang telah ada dapat dilihat pada Gambar 5. 


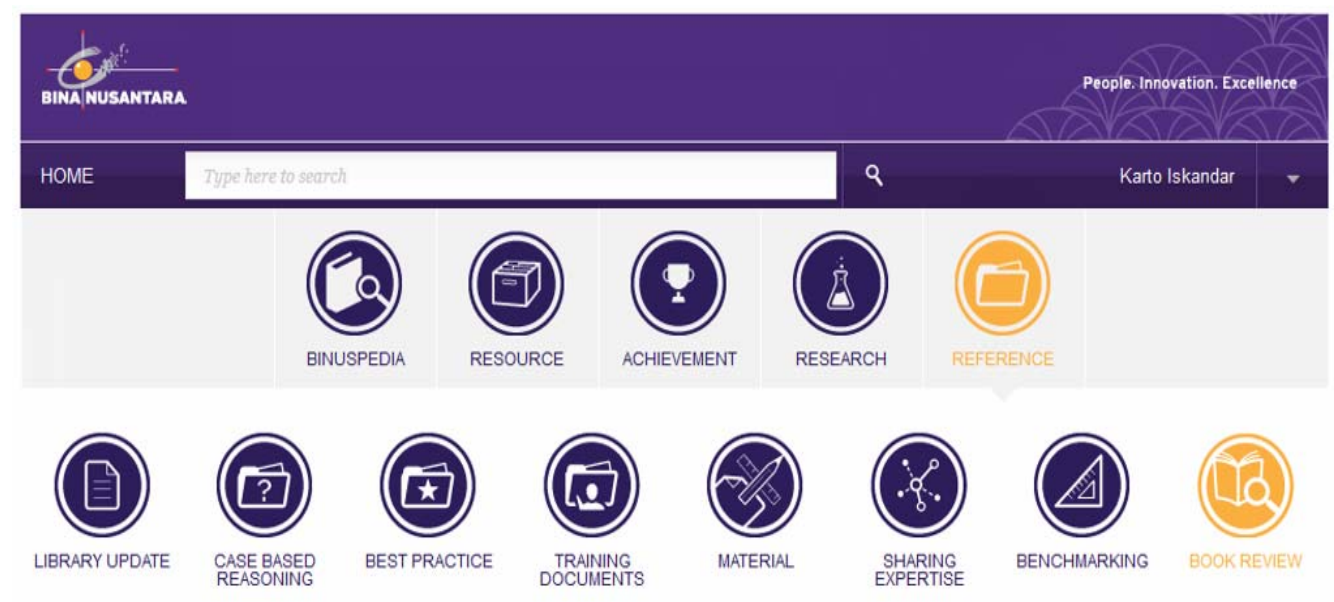

Gambar 5 Aplikasi Review Buku dalam KMS BINUS

\section{Tampilan Layar}

Pada layar aplikasi Review Buku terdapat informasi singkat penjelasan aplikasi ini. Bagian ini berguna untuk menjelaskan kepada pembaca KMS agar memahami kegunaan dari aplikasi ini (Altschiller \& Wenzel, 2003). Kemudian, aplikasi ini juga memiliki fitur pencarian karena fitur ini merupakan hal yang sangat penting dalam hal penggunaan kembali knowledge. Fitur pencarian ini sangat berguna ketika pengguna menginginkan cara cepat untuk mendapatkan dokumen yang dibutuhkan. Pada bagian bawah fitur pencarian, terdapat list buku yang telah di-review. Untuk melihat detail dari book review seperti judul buku, pengarang, pelaku review buku, jumlah halaman buku, cover buku, ukuran buku, waktu review, dan lain-lain, pembaca harus mengklik review buku.

Tampilan layar aplikasi review buku dapat dilihat pada Gambar 6. Pada layar kiri terdapat pengelompokan konten berdasarkan kategori. Kemudian di tengah atas terdapat penjelasan singkat. Penjelasan ini berguna bagi pengguna untuk mengetahui manfaat dari aplikasi ini. Kemudian di bawahnya terdapat fitur pencarian. Pada pencarian ini user dapat memilih pencarian apakah pada semua aplikasi KMS, atau pada aplikasi Book Review saja. Kemudian di bagian bawah terdapat list konten Book Review yang sudah ada. Guna mempermudah user mencari, pada aplikasi Book Review ini, user dapat melakukan sorting atau pengurutan terhadap semua field yang tampil, juga dapat melakukan filter atau pencarian berdasarkan field yang diinginkan. Misalnya saja melakukan pencarian filter berdasarkan pembuat review buku atau berdasarkan pengarang buku. Fitur ini sangat berguna bagi user dalam melakukan pencarian terhadap daftar buku yang telah di-review.

Setelah membaca hasil review buku, kemudian user dapat berinteraksi dengan reviewer dengan memberikan komentar. Pemberian komentar ini sangat penting untuk berinteraksi ataupun berdiskusi antara reviewer dengan pembaca review buku (Huang \& Yang, 2010). Agar reviewer mengetahui ada yang membaca dan memberikan komentar, sistem KMS akan mengirimkan notification dalam bentuk email kepada reviewer. Dengan adanya sistem kirim email otomatis ini, diharapkan reviewer dapat dengan cepat menjawab komentar yang diberikan. Dengan adanya sistem ini diharapkan menumbuhkan budaya review buku dan antara reviewer dan pembaca dapat berinteraksi dalam diskusi. 


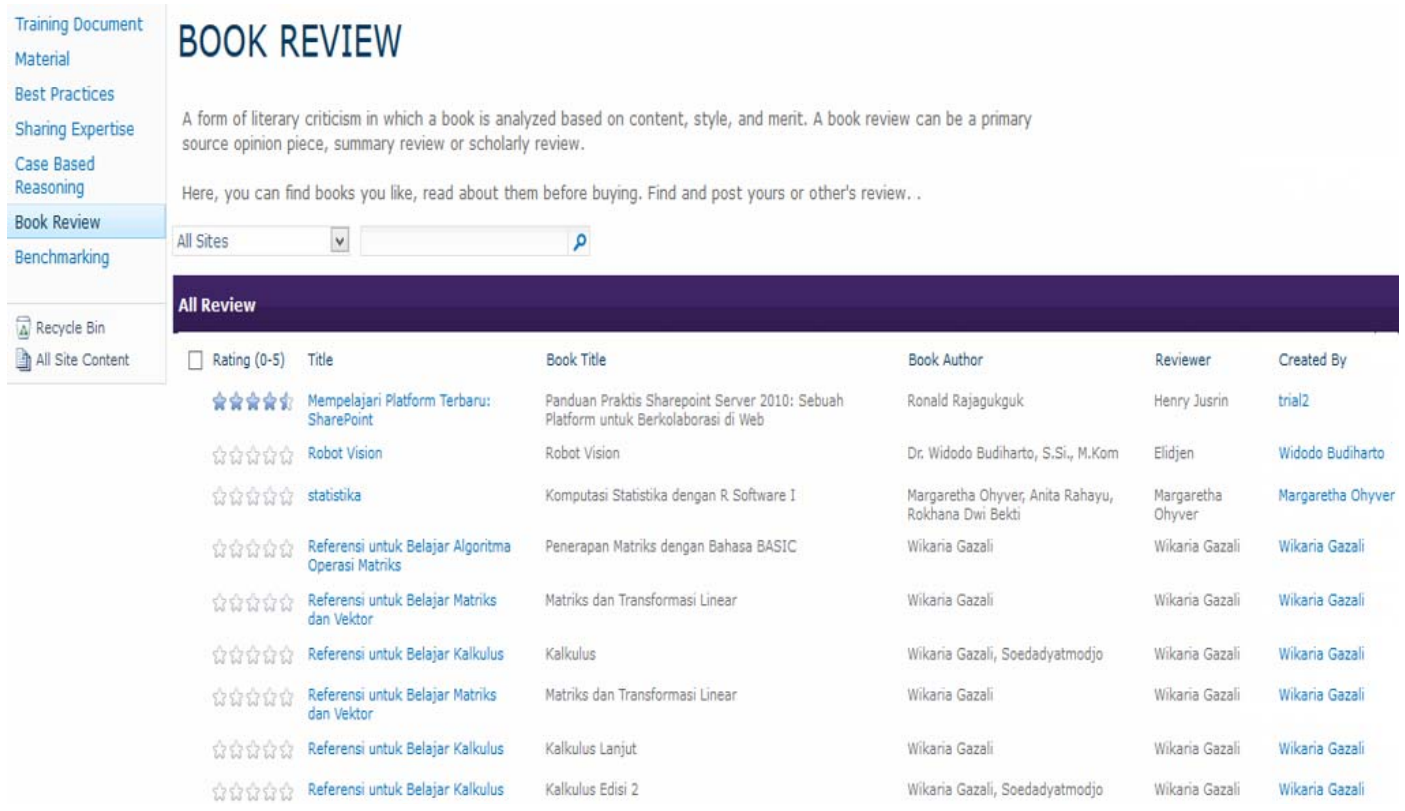

Gambar 6 Tampilan Layar Aplikasi Book Review

Penggunaan aplikasi KMS yang sudah dibangun sebelumnya cukup efektif, terbukti dengan terus meningkatnya user pengguna aktif yang tercatat pada log pengguna aktif aplikasi KMS (Jenkins, 1999). Perkembangan jumlah user aktif dapat dilihat pada Gambar 7. Banyaknya pengguna aktif menandakan banyaknya pengguna, dan diharapkan dengan penambahan aplikasi Review Buku ini dapat dengan cepat diterima sehingga mengakibatkan peningkatan konten dalam KMS.

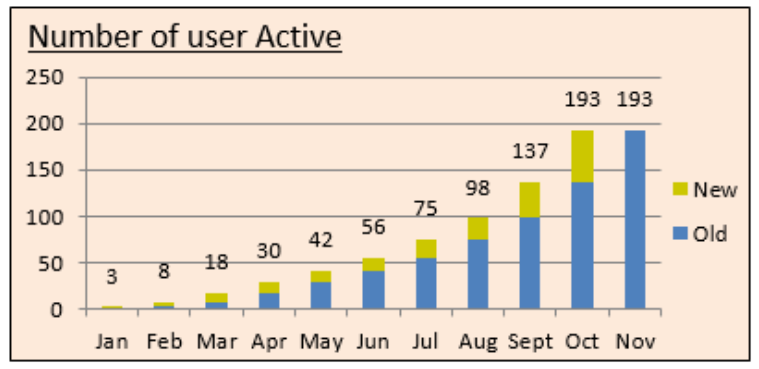

Gambar 7 Grafik Perkembangan User Aktif

\section{SIMPULAN}

Berdasarkan hasil penelitian yang dilakukan pada kebutuhan Knowledge Management pada Bina Nusantara akan aplikasi Review Buku, maka dapat disimpulkan bahwa dengan adanya sistem review buku yang dirancang dapat memfasilitasi tenaga pengajar, dosen, guru, dan karyawan untuk melakukan review buku. Aplikasi Book Review pada KMS Bina Nusantara dapat mendorong pelaku review buku dan memfasilitasi pelaku review buku dan pembaca review untuk berdiskusi dan berinteraksi lebih optimal. Adanya pembagian akses dan pengenalan pelaku review buku, antara pembaca dan pe-review buku dapat saling kenal, berinteraksi, membuat diskusi menjadi lebih efektif. Adanya fitur search untuk melakukan pencarian hasil review buku di dalam aplikasi KM ini. Saran untuk pengembangan review buku selanjutnya dapat ditambahkan beberapa fitur lainnya seperti like, follow, dan quotation, sehingga membuat aplikasi Review Buku ini menjadi lebih menarik dan lebih interaktif. 


\section{DAFTAR PUSTAKA}

Altschiller, D. \& Wenzel, S. G. (2003). Finding book reviews in print and online. ProQuest Journal, 42(3), 193 - 198, 200 - 205.

Chen, Z., \& Xu, X. (2010). Study on construction of Knowledge Management System based on enhancing core competence of industrial clusters. International Journal of Business and Management, 5(3), 217-222.

Evers, H.-D., Gerke, S., \& Menkhoff, T. (2010). Knowledge clusters and knowledge hubs: designing epistemic landscapes for development. Journal of Knowledge Management, 14(5), 678-689.

Groff, T. R., \& Jones, T. P. (2003). Introduction to Knowledge Management: KM in Business. Burlington: Butterworth-Heinemann.

Huang, Y. K. \& Yang, W. I. (2010). A study of internet book reviews and borrowing intention. Library Review, 59(7), 512-521.

Huang, Y. K. \& Yang, W. I. (2010). Dissemination motives and effects of internet book reviews. The Electronic Library, 28(6), 804-817.

Huang, Y. K. \& Yang, W. I. (2008). Motives for and consequences of reading internet book reviews. The Electronic Library, 26(1), 97-110.

Iskandar, K., Tony., Phankova, C. H., \& Agustino, W. (2013). Perancangan dan implementasi Knowledge Management System pada IT Division Bina Nusantara Berbasis Microsoft SharePoint 2013. Bina Nusantara-Jakarta.

Jenkins, P. O. (1999). Book reviews and faculty book selection. ProQuest Journal, 18(1), 4 - 5.

Liu, Duen-Ren., Chen, Wei-Hsiao., \& Chiu, Po-Huan. (2013). Recommending quality book reviews from heterogeneous websites. Internet Research, 23(1), 27-46.

O’Brien, J.A., \& Marakas, G. M. (2009). Introduction to Information Systems. 15th Ed. New York: McGraw-Hill.

Pialorsi, P. (2011). Microsoft SharePoint 2010 Developer Reference. Sebastopol: O’Reilly Media.

Pressman, R. (2010). Software Engineering: A practitioner's approach. 7th Ed. New York: McGrawHill.

Rajagukguk, R. (2010). Panduan Praktis SharePoint Server 2010. Jakarta: Elex Media Komputindo.

Tobing, P. L. (2007). Knowledge Management: Konsep, Arsitektur dan Implementasi. Yogyakarta: Graha Ilmu.

Zinkhan, G. M. \& Clark, T. (1995). The role of books and book reviews in the knowledge dissemination process. Journal of Marketing, 59(3), 106-108. 